\title{
Antimicrobial Activity of Some Complexes of $\mathrm{Zr}$ (IV) and Cd (II) with Benzaldazine Derivatives on Growth of Some Pathogenic Bacteria
}

\author{
Nahida Saieed Al-Chalabi ${ }^{1 *}$, Najwa Ibrahim Al-Barhawi ${ }^{2}$, Zohour Fathi Daood ${ }^{3}$ \\ ${ }^{1 *}$ Dept. of Environment Sciences, College of Environmental Sciences and Technology, University of Mosul, \\ IRAQ \\ ${ }^{2}$ Dept. of Biology, College of Education for Pure Sciences, University of Mosul, Mosul, IRAQ \\ ${ }^{3}$ Dept. of Chemistry, College of Education for Pure Sciences, University of Mosul, Mosul, IRAQ \\ E-mail: ${ }^{1 *}$ nahidaal-chalabi@uomosul.edu.iq, ${ }^{2}$ dr.najwa@uomosul.edu.iq, ${ }^{3}$ pdzfataee@ uomosul.edu.iq
}

(Received May 15, 2021; Accepted June 15, 2021; Available online August 28, 2021)

DOI: 10.33899/edusj.2000.168655, (C) 2021, College of Education for Pure Science, University of Mosul.

This is an open access article under the CC BY 4.0 license (http://creativecommons.org/licenses/by/4.0/).

\begin{abstract}
In order to understand the medical effects of heavy metals, the antimicrobial effect of Cd (II) metal ion, $\mathrm{Zr}$ (IV) metal ion, Ligand and their complex compounds resulting from their combination, was studied on the growth of gram negative and positive bacteria as well as yeast. It turns out, that all bacterial isolates (Bacillus subtilus, Stapphylococcus aureus and Pseudomonas aeuroginosa, Escherichia coli, Klebsiella pneumonia, Proteus vulgaris, Salmonella typhi, Shigella flexneri and the yeast Candida albicans), have a high resistance of $100 \%$ to Colistin $(10 \mu \mathrm{g} / \mathrm{disc})$ and Nystatin $(10 \mu \mathrm{g} / \mathrm{disc})$, while the $\mathrm{Zr}$ (IV) metal is better than Cd metal in its effect on inhibiting the growth of different types of pathogenic bacteria isolated in this study.In the study of minimum inhibition concentration (MIC) of metal Cd (II), $\mathrm{Zr}$ (IV) and, Ligand complexes, on the growth of bacterial isolates, it was also shown that $\mathrm{Cd}$ and Ligand 4-bromobenzaldazine (BrA) at the concentration $0.00025 \mathrm{~g} / \mathrm{ml}$, had an effect of 88 and $100 \%$ as the lowest inhibitory concentration for the growth of all bacterial isolates of different species.
\end{abstract}

Keyword: Heavy metals, Pathogenic bacteria, Antibiotics.

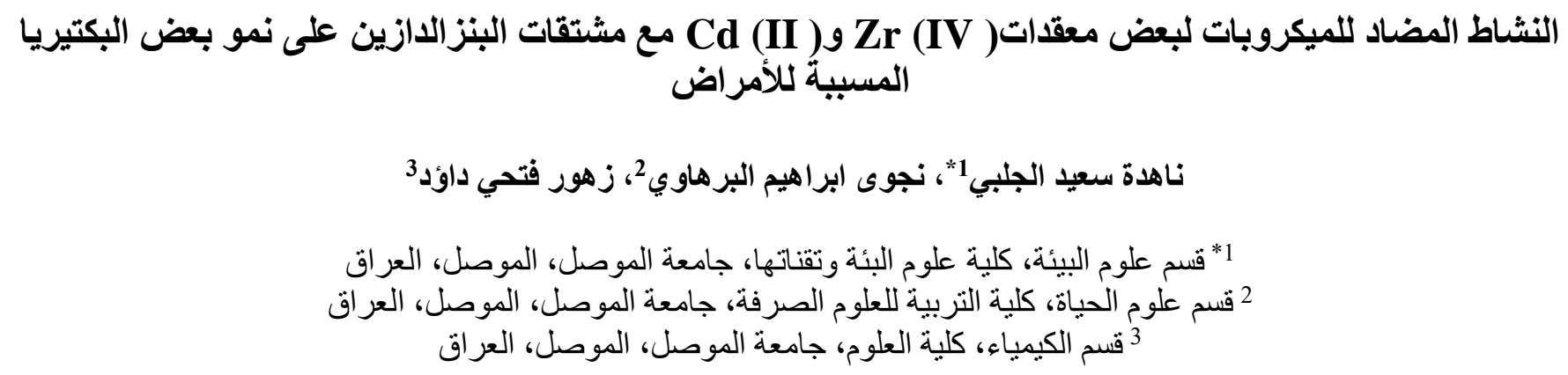




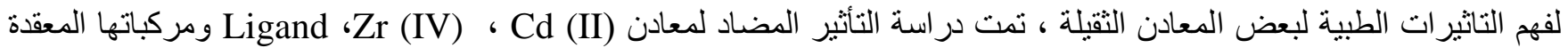

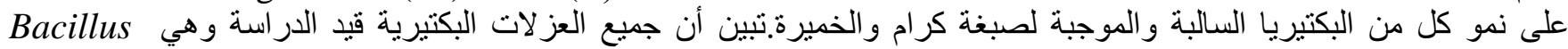
Klebsiella ، Escherichia coli ، Pseudomonas aeuroginosa ، Stapphylococcus aureus ، subtilus Sandida albicans وخميرة Shigella flexneri ، Salmonella ، Proteus vulgaris ، pneumonia

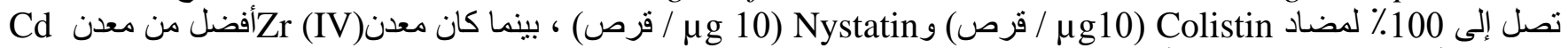

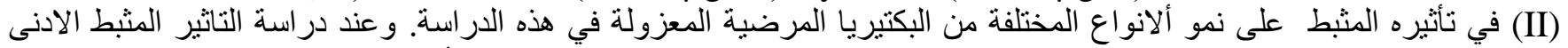

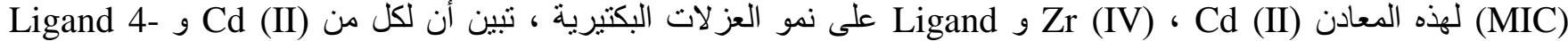
bromobenzaldazine (BrA) و عند التركيز تركيز مثبط لنمو جميع العز لات البكتيرية بانو اعها المختلفة.

الكلمات المفتاحية : المعادن الثقيلة، البكتيريا المرضية، المضادات الحيوية

\section{Introduction}

Several metal complexes are known to display antimicrobial activity which is due either to the metallic ion or to the ligands [1]. Generally, the bioactivity of complexes is closely related to their structure, solubility [2], thermostability and kinetic lability [3].Azine complexes with some ions of the transition elements series have arounsed considerable interest.In these complexes the ligands have been coordinated in the different manners [4].

Heavy metals have been used as antimicrobial agents since ancient times, but many of them have an unclear path of influence. Recent studies have shown that different minerals cause distinct different forms of infections to microbes, such as impaired protein function or damage to cell membranes, and despite their known toxicity, but they can be used as antimicrobial agents and alternatives to antibiotics, [5]. Currently, the use of these minerals as antimicrobials has been restricted due to the expected negative impact on human health or toxic effects on agricultural crops [6]. Recently, Escherichia coli E-30 and Klebsiella pneumoniae K-6 have proven to be effective in creating nanoparticles with cadmium sulfide and have been shown to be better than chemically manufactured nanoparticles of cadmium sulfide as antimicrobial activity for the growth of both pathogenic fungi and bacteria, as well as their importance in absorbing heavy metals and removing toxins from the environment, [7].

The aim of this study: Due to the lack of discussion in previous studies about the anti-effect of the elements CdII and ZrIV in a free or complicated manner with some ligands on some types of bacteria causing various diseases as alternatives to antibiotics that have become more resistant by these bacteria and thus few opportunities to use them as a treatment to eliminate them.

\section{Research Method}

\section{Collection of samples:}

Samples were collected in the form of swabs from the affected skin, urine, and swabs from the oral cavity, for patients attending Al Salam Hospital of different ages and genders.

\section{Cultivation of specimens:}

Samples taken from the affected skin were cultivated on the nutrient agar, the blood agar and KIA media, while the urine samples were cultivated into the blood agar, EMB agar, ENDO agar and MacConkey agar media. Stool samples were also cultivated on the media of the blood agar and MacConkey agar, while the samples taken from the oral cavity were cultured on the sabourauds broth and agar medium as well as the Hi-chrome medium and Candida agar, By streaking method to obtain 
Journal of Education and Science (ISSN 1812-125X), Vol: 30, No: 3, 2021 (63-72)

Special Issue for Proceeding of $3^{\text {rd }}$ National (1 ${ }^{\text {st }}$ international conference of biology) (ICBSUM 2021) 5, 6 July

College of Education for Pure Science, University of Mosul, Mosul, Iraq.

isolated and pure colonies, and incubated inverted in the growth incubator at a temperature of $37^{\circ} \mathrm{C}$ for 24-48 hours.

\section{Identification of bacterial isolates:}

Bacterial isolates were identified by:

1-Morphological and cultural characteristic of bacterial colonies:

The characteristics of the growing bacterial colonies were noted in terms of their color, shape, and texture, [8].

\section{2-Microscopical characteristic:}

Smeare of pure colonies were made on clean glass strips to dyed with gram stain and examined by the major forces $(100 \mathrm{X})$ of the complex optical microscope, Cell types were then observed, arranged and their responded to the gram stain, [8].

\section{3-Biochemical test:}

Several biochemical tests were used for each isolated bacterial species and yeast depending on what is indicated by [9] and [10] .

\section{Complexes of Zr (IV) and Cd (II) with Benzaldazine Derivatives:}

Obtained them from a previous study [11].

\section{Determination of the biological activity of antibiotics, metals, ligands and azine complexes:}

The biological activity has been estimated by the filter paper disc and the minimal inhibition concentration methods [1]. An overnight culture of isolated microorganisms grown at $37^{\circ} \mathrm{c}$ in the nutrient broth medium, then a sample of $0.5 \mathrm{ml}$ of each microorganism was spread over a surface of a nutrient agar medium dish, these dishes were divided into two sections, the first section was distributed the discs on their surface of the six antibiotic: Colistin (Col)10 $\mu \mathrm{g} / \mathrm{disc}$, Nystatin (Ny)10 $\mu \mathrm{g} / \mathrm{disc}$, Neomycin (N)10 $\mu \mathrm{g} / \mathrm{disc}$, Erythromycin (Er) $15 \mu \mathrm{g} / \mathrm{disc}$, Trimethiprim (Tri) $25 \mu \mathrm{g} / \mathrm{disc}$, Cephalexine

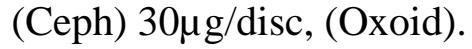

while the second section was distributed on the surface of the that were prepared in- vitro (Discs of filter paper, Whatman No.1), $6 \mathrm{~mm}$ in diameter, were sterilized at $140^{\circ} \mathrm{C}$ for $1 \mathrm{hr} .100$ discs were immersed in $1 \mathrm{ml}$ with a concentration of $0.025 \mathrm{~g} / \mathrm{ml} / \mathrm{disc}$ of the solution each of metal ions $\mathrm{Zr}$ (IV), Cd (II) of zirconium, cadmium nitrate salts, ligand and their complexes.Three replicates per section, and then incubated all dishes at a temperature of 37c and on the second day read the results depending on the diameter of the inhibition zone measured in $\mathrm{mm}$ [9].We make the series dilution of the decreasing concentrations from the original solution $0.025 \mathrm{~g} / \mathrm{ml}$ we attended the following concentrations: 0.01 , $0.002,0.001,0.0005,0.00025,0.00005 \mathrm{~g} / \mathrm{ml}$, in order to estimate the minimum inhibition concentration (MIC) value for each bacterial species used in this study.

\section{Statistical analysis:}

The data were statistically analyzed using T-test in SPSS ver. 15 at P 0.05> to determine if there are significant differences between the effect of $\mathrm{Zr}$ (IV), Cd (II), Ligand and the complexes resulting from their interaction, on the growth of both negative and positive gram bacteria in terms of the values of the inhibition zone around the discs saturated with these substances and fixed on the surface of the fertilized medium with these bacteria.

\section{Results and Discussion:}




\section{Journal of Education and Science (ISSN 1812-125X), Vol: 30, No: 3, 2021 (63-72) \\ Special Issue for Proceeding of $3^{\text {rd }}$ National (1st international conference of biology) (ICBSUM 2021) 5, 6 July College of Education for Pure Science, University of Mosul, Mosul, Iraq.}

By studying the microbiological and cultural properties of the bacterial isolates, it was found that they belong to the following bacterial species according to the isolated samples.

The bacteria isolated from the skin infections: One bacterial colony was easily characterized by its growth on the Nutrient agar medium after incubation for 24 hours at $37^{\circ} \mathrm{C}$, and the colonies appeared white color and aqueous textures, while its cells were in the form of single bacillus or short chains containing spores and positive for the gram stain. Other bacteria appeared apeared in a yellowish-brown color with a diameter of 1-2 mm, with full analysis of red blood cells ( $\beta$-heamolysis )after incubation for 24 hours at $37^{\circ} \mathrm{C}$ on the blood agar medium, as well as its ability to grow a golden yellow color on the selective medium Mannitol salt agar. When the cells were diagnosed microscopically, they were spherical cells, positive for gram stain, which are in the form of single, double, or clustered.

On the other hand, large, flat, hemolytic, and dye-producing colonies are formed in the medium of the blood agar, giving it a dark greenish-blue color with the formation of a metallic sheen layer on the surface of these colonies, While the growing colonies on the sloping part of the KIA medium gave a reddish pink color with a metallic sheen appearance, and the bottom of the tube is the same color with no gas and hydrogen sulfide $\left(\mathrm{H}_{2} \mathrm{~S}\right)$. Their cells appeared to be negative bacilii for gram stain, with the inability to form spores when examined by optical microscopy. The results of biochemical tests (Tebal, 1), showed that the isolated bacteria are Bacillus subtilus, Stapphylococcus aureus and Pseudomonas aeuroginosa, respectively.

The bacteria isolated from the urine samples: determined when growing on the blood agar medim and incubated for 24 hours at a temperature of $37^{\circ} \mathrm{C}$, the strength of the developing colonies was viscous with a diameter of 1-4 mm with analysis of red blood cells. While on the medium of the Eosin methylene blue, the colonies appeared blue to green metalic sheen, while the colonies of these bacteria appeared on the medium of ENDO agar in a dark red color to gold metalic sheen. When examining their cells with an optical microscope, It was found to be in the form of Bacillus-negative to gram stain and not sporeforming. After culturing the urine sample on the blood agar medium, the colonies of these bacteria appeared in a large size with a viscous and white-gray color. While its colonies on the MacConky agar medium, were pink in color indicating their fermentation of lactose sugar in this medium as well as their mucous texture. Their cells appeared to be negative bacilii for the gram stain, and not spore-forming when examined by an optical microscope. Other colonies were characterized on the medium of the blood agar in the form of swarming growth and fish oder, While on EMB agar appeared in the form of transparent colonies due to its inability to ferment lactose sugar. Their cells appeared to be negative bacilii for the gram stain, and not spore-forming when examined by an optical microscope. While its growth on the MacConky agar medium was characterized by its inability to ferment lactose sugar and loss of swarming phenomina. Their cells appeared to be negative bacilii for gram stain, with the inability to form spores when examined by optical microscopy. The results of biochemical tests ( Tabel 1), showed that the isolated bacteria are Escherichia coli, Klebsiella pneumonia, Proteus vulgarise respectively.

The bacteria isolated from the stool: White gray colonies appeared on the medium of blood agar with a diameter of about $2 \mathrm{~mm}$, and analysis of red blood cells. On the medium of the MacConky agar was a pale color due to its inability to ferment lactose sugar in this medium, but it on the Bismuth sulfate agar appeared colonies of black color with the formation of green metallic sheen, its cells when examined under the microscope, showed to be negative bacilii for the gram stain, and not spore-forming. On the other hand, small colonies of 1-2 $\mathrm{mm}$ in diameter, colorless due to their inability to ferment lactose sugar, appeared on the medium of MacConkey agar, and their cells appear under the microscope in the form of negative bacilli gram stain. The results of biochemical tests ( Tabel 1), showed that the isolated bacteria are, Salmonella typhi, Shigella flexneri Respectively. 
The yeast isolated from the oral cavity: When inoculating the Sabourauds Dextrose broth medium with a swab taken from the oral cavity and incubate the culture tubes at $37^{\circ} \mathrm{C}$ for $24-48$ hours, we observed the development of turbidity in this medium, while on the Sabourauds Dextrose agar, we showed smooth creamy white colonies with characteristic yeast odour, on Hichrome candida agar yeast cell produced green color colonies, and in the gram stain smear, the cell apprared as budding yeast. Fermentation of the sugars contained in Table ( 1 ) confirms this yeast is Candida albicans.

Table (1): The biochemical tests of the isolated bacteria.

\begin{tabular}{|c|c|c|c|}
\hline & \multirow[b]{2}{*}{ Shape } & \multirow[b]{2}{*}{ Sample } & \multirow[b]{2}{*}{ Biochemical test } \\
\hline $\begin{array}{l}\text { Bacteria } \\
\text { Gram + ve }\end{array}$ & & & \\
\hline B.subtilus & $+\operatorname{Rod}$ & $\begin{array}{c}\text { Skin } \\
\text { infections }\end{array}$ & Oxidase (-), Catalase (+), Urease (-), TSI (+), Nitrate reduction $(+)$ \\
\hline S.aureus & + Cocci & $\begin{array}{c}\text { Skin } \\
\text { infections }\end{array}$ & $\begin{array}{c}\text { Coagulase (+), Calalase (+), DNase (+), Mannitol (+), Sucrose (+), } \\
\text { Trechalose }(+)\end{array}$ \\
\hline \multicolumn{4}{|l|}{ Gram - ve } \\
\hline E.coli & - Rod & Urine & $\begin{array}{c}\text { IMViC (++--), LDC (+), } \beta \text {-GUR (+), Nitrate reduction (+), Lactose (+), } \\
\text { Urease (-) }\end{array}$ \\
\hline S. typhi & - Rod & Stool & 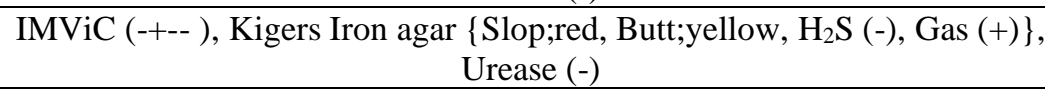 \\
\hline P. aeuroginosa & - Rod & $\begin{array}{c}\text { Skin } \\
\text { infections }\end{array}$ & Calalase $(+)$, Oxidase $(+)$, Glucose $(+$, Acid $)$, Maniitol $(+$, Acid $)$ \\
\hline P.vulgaris & - Rod & Urine & IMViC (-+-+ ), Urease (+), $\mathrm{H}_{2} \mathrm{~S}(+)$, PDA (+), ONPG (-) \\
\hline K. pneumonia & - Rod & Urine & $\begin{array}{c}\text { IMViC (--++ ), ODC (-), } \mathrm{H}_{2} \mathrm{~S}(-), \text { Lactose (- ), Urease (+), Malonate (+), } \\
\text { LDC (-) }\end{array}$ \\
\hline S.flexneri & - Rod & Stool & IMViC (++--), ONPG (-), $\mathrm{H}_{2} \mathrm{~S}(-)$, Oxidase (-), Urease (-), LDC (-) \\
\hline \multicolumn{4}{|l|}{ Yeast } \\
\hline C.albicans & + Cocci & oral cavity & Glucose $(+)$, Catalase $(+)$, Sucrose $(+)$, Urease $(-), \beta$-MAL, $\beta$-GUR (-) \\
\hline
\end{tabular}

LDC; Lysine decarboxylase, $\beta$-GUR; $\beta$ - glucuronidase, ONPG; $\beta$-galactosidase, $\beta$-MAL; $\beta$-Maltosidase, ODC; Ornithine decarboxylase, PDA; Phenylalanine deaminase.

The antibiotic sensitivity test for all antibiotics to their positive and negative types of gram stain used in this study was carried out, by culturing bacterial isolates by brushing method on the sensitivity test medium, as described in the materials and methods of work.The results in Table (2), show that all bacterial isolates have a high resistance of $100 \%$ to Col, $\mathrm{Ny}$, while resistance to N, Er, Tri, and Ceph has the following percentages: 22, 56, 89 and 44\% respectively.It is clear that the Col and Ny reached the highest degree of resistance, while the resistance to $\mathrm{N}$ was the lowest, this may be due to the sensitivity of most bacterial isolates to this antibiotic.The resistance of bacteria to antibiotics has become a very serious health problem, caused by repeated and incorrect use of these antibiotics without a prescription [12][13].Note that this resistance may be natural or acquired with mutations or by processes of genetic transformation or bacterial conjugation or Transduction [14] [15]. This resistance is encoded by special genes located on plasmids, which process the efflux pump of these antibiotics and put them out of the bacterial cell by cellular transport systems, or by encoding special enzymes that inhibit the action of these antibiotics [16], or make a change in the effective site (target) of the antibiotic receptors present on the surface of the bacterial cell [17], it is possible that there may be several genes responsible for the resistance of several antibiotics in a single bacterial cell [18]. 
Journal of Education and Science (ISSN 1812-125X), Vol: 30, No: 3, 2021 (63-72)

Special Issue for Proceeding of $3^{\text {rd }}$ National (1 ${ }^{\text {st }}$ international conference of biology) (ICBSUM 2021) 5, 6 July

College of Education for Pure Science, University of Mosul, Mosul, Iraq.

Table (2): The antibiotic sensitivity test for six antibiotics on growth of positive and negative types of gram stain bacteria.

\begin{tabular}{|c|c|c|c|c|c|c|}
\hline \multirow{2}{*}{ Bacteria } & \multicolumn{6}{|c|}{ Antibiotics $(\mu \mathrm{g} /$ disc $)$} \\
\hline & $\begin{array}{l}\text { Col } \\
(10)\end{array}$ & $\begin{array}{l}\text { Ny } \\
(10)\end{array}$ & $\begin{array}{c}\mathrm{N} \\
(10)\end{array}$ & $\begin{array}{c}\mathrm{Er} \\
(15)\end{array}$ & $\begin{array}{l}\text { Tri } \\
(25)\end{array}$ & $\begin{array}{r}\text { Ceph } \\
(30) \\
\end{array}$ \\
\hline B.subtilus & $\mathrm{R}$ & $\mathrm{R}$ & $\mathrm{S}$ & $\mathrm{S}$ & $\mathrm{R}$ & $\mathrm{S}$ \\
\hline \multicolumn{7}{|l|}{ Gram - ve } \\
\hline E.coli & $\mathrm{R}$ & $\mathrm{R}$ & $\mathrm{S}$ & $\mathrm{S}$ & $\mathrm{R}$ & $\mathrm{S}$ \\
\hline P.vulgaris & $\mathrm{R}$ & $\mathrm{R}$ & $S$ & $\mathrm{R}$ & $\mathrm{R}$ & $\mathrm{S}$ \\
\hline K. pneumonia & $\mathrm{R}$ & $\mathrm{R}$ & $\mathrm{R}$ & $\mathrm{R}$ & $\mathrm{R}$ & $\mathrm{R}$ \\
\hline S.flexneri & $\mathrm{R}$ & $\mathrm{R}$ & $\mathrm{S}$ & $\mathrm{R}$ & $\mathrm{R}$ & $\mathrm{R}$ \\
\hline C.albicans & $\mathrm{R}$ & $\mathrm{R}$ & $\mathrm{R}$ & $\mathrm{R}$ & $\mathrm{R}$ & $\mathrm{R}$ \\
\hline $\mathrm{R} \%$ & 100 & 100 & 22 & 56 & 89 & 44 \\
\hline
\end{tabular}

Col: Colistin, Ny: Nystatin, N: Neomycin, Er: Erythromycin, Tri: Trimethiprim, Ceph: Cephalexin

When conducting bacterial sensitivity to heavy metals, the results in Table (3) showed that all bacterial isolates were resistant to: $\mathrm{Zr}$ (IV) metal, to all Ligand species, as well as to the complex of Ligand-Zr (IV), with a percentage of $100 \%$, except for the complex Ligand BrA where resistance to bacteria $77 \%$.On the other hand, a significant decrease was observed in the resistance of these isolates to the metal $\mathrm{Cd}$ (II) and reached to $33 \%$, but this resistance rose up to 77 and $88 \%$ when using the complex Ligand-Cd (II), except for the complex of this metal with Ligand BrA where the bacteria showed a weak resistance of only $22 \%$, which means that the complex is more effective than free Ligand, while [19] mentioned that the free ligand and some metal complexes possess antimicrobial activities towards four type of bacteria and five types of fungi, especially against Staphylococcus aureus and Pseudomonas aeroginosa[20].

The high resistance exhibited by these positive and negative bacterial isolates of gram stain for both antibiotics and heavy metals is likely due to the occurrence of genes for these two types of resistance on the same plasmid [21]. There was a correlation between the tolerance of some isolates of heavy metals and their resistance to antibiotics., these isolates showed tolerance of more than one heavy metal with resistance to one or more antibiotics [22]. 
Journal of Education and Science (ISSN 1812-125X), Vol: 30, No: 3, 2021 (63-72)

Special Issue for Proceeding of $3^{\text {rd }}$ National (1 ${ }^{\text {st }}$ international conference of biology) (ICBSUM 2021) 5, 6 July

College of Education for Pure Science, University of Mosul, Mosul, Iraq.

Table (3): Antimicrobial activity of $\mathrm{Zr}$ (IV) and Cd (II) metal complexes of ligands on growth of positive and negative types of gram stain bacteria.

\begin{tabular}{|c|c|c|c|c|c|c|c|c|c|c|c|c|c|c|c|c|c|}
\hline \multirow{4}{*}{$\begin{array}{l}\text { Bacteria } \\
\text { ram+ve }\end{array}$} & \multirow{2}{*}{\multicolumn{2}{|c|}{ Metal }} & \multirow{2}{*}{\multicolumn{5}{|c|}{ Ligands }} & \multirow{2}{*}{\multicolumn{10}{|c|}{ Complexes of }} \\
\hline & & & & & & & & & & & & & & & & & \\
\hline & \multirow[b]{2}{*}{$\begin{array}{l}\mathrm{Zr} \\
\text { (IV) }\end{array}$} & \multirow[b]{2}{*}{$\begin{array}{l}\mathrm{Cd} \\
\text { (II) }\end{array}$} & \multirow[b]{2}{*}{ A } & \multirow[b]{2}{*}{ B } & \multirow[b]{2}{*}{$\mathrm{C}$} & \multirow[b]{2}{*}{$\mathrm{D}$} & \multirow[b]{2}{*}{$\mathrm{E}$} & \multicolumn{5}{|c|}{$\mathrm{Zr}$ (IV) with Ligands } & \multicolumn{5}{|c|}{ Cd (II)with Ligands } \\
\hline & & & & & & & & A & B & $\mathrm{C}$ & $\mathrm{D}$ & $\mathrm{E}$ & $\mathrm{A}$ & $\mathrm{B}$ & $\mathrm{C}$ & $\mathrm{D}$ & $\mathrm{E}$ \\
\hline $\begin{array}{c}B . \\
\text { Subtilus }\end{array}$ & $\mathrm{R}$ & $S$ & $\mathrm{R}$ & $\mathrm{R}$ & $\mathrm{R}$ & $\mathrm{R}$ & $\mathrm{R}$ & $\mathrm{R}$ & $\mathrm{R}$ & $\mathrm{R}$ & $\mathrm{R}$ & $\mathrm{R}$ & $\mathrm{S}$ & $\mathrm{S}$ & $\mathrm{R}$ & $\mathrm{R}$ & S \\
\hline $\begin{array}{c}S . \\
\text { Aureus }\end{array}$ & $\mathrm{R}$ & S & $\mathrm{R}$ & $\mathrm{R}$ & $\mathrm{R}$ & $\mathrm{R}$ & $\mathrm{R}$ & $\mathrm{R}$ & $\mathrm{R}$ & $\mathrm{R}$ & $\mathrm{R}$ & $\mathrm{R}$ & $\mathrm{R}$ & $\mathrm{R}$ & $\mathrm{R}$ & $\mathrm{R}$ & $\mathrm{R}$ \\
\hline \multicolumn{18}{|l|}{ Gram- ve } \\
\hline E.coli & $\mathrm{R}$ & $\mathrm{R}$ & $\mathrm{R}$ & $\mathrm{R}$ & $\mathrm{R}$ & $\mathrm{R}$ & $S$ & $\mathrm{R}$ & $\mathrm{R}$ & $\mathrm{R}$ & $\mathrm{R}$ & $\mathrm{R}$ & $\mathrm{R}$ & $\mathrm{R}$ & $\mathrm{R}$ & $\mathrm{R}$ & $S$ \\
\hline S.typhi & $\mathrm{R}$ & $\mathrm{S}$ & $\mathrm{R}$ & $\mathrm{R}$ & $\mathrm{R}$ & $\mathrm{R}$ & $S$ & $\mathrm{R}$ & $\mathrm{R}$ & $\mathrm{R}$ & $\mathrm{R}$ & $\mathrm{R}$ & $\mathrm{R}$ & $\mathrm{R}$ & $\mathrm{R}$ & $\mathrm{R}$ & $\mathrm{S}$ \\
\hline P.aeuroginosa & $\mathrm{R}$ & $\mathrm{R}$ & $\mathrm{R}$ & $\mathrm{R}$ & $\mathrm{R}$ & $\mathrm{R}$ & $\mathrm{R}$ & $\mathrm{R}$ & $\mathrm{R}$ & $\mathrm{R}$ & $\mathrm{R}$ & $\mathrm{R}$ & $\mathrm{R}$ & $\mathrm{R}$ & $\mathrm{R}$ & $\mathrm{R}$ & $\mathrm{R}$ \\
\hline $\begin{array}{c}P . \\
\text { vulgaris }\end{array}$ & $\mathrm{R}$ & $S$ & $\mathrm{R}$ & $\mathrm{R}$ & $\mathrm{R}$ & $\mathrm{R}$ & $\mathrm{R}$ & $\mathrm{R}$ & $\mathrm{R}$ & $\mathrm{R}$ & $\mathrm{R}$ & $\mathrm{R}$ & $\mathrm{R}$ & $\mathrm{R}$ & $\mathrm{R}$ & $\mathrm{R}$ & S \\
\hline K.pneumonia & $\mathrm{R}$ & $S$ & $\mathrm{R}$ & $\mathrm{R}$ & $\mathrm{R}$ & $\mathrm{R}$ & $\mathrm{S}$ & $\mathrm{R}$ & $\mathrm{R}$ & $\mathrm{R}$ & $\mathrm{R}$ & $\mathrm{R}$ & $\mathrm{R}$ & $\mathrm{R}$ & $\mathrm{R}$ & $\mathrm{R}$ & $S$ \\
\hline $\begin{array}{c}S . \\
\text { Flexneri }\end{array}$ & $\mathrm{R}$ & $\mathrm{R}$ & $\mathrm{R}$ & $\mathrm{R}$ & $\mathrm{R}$ & $\mathrm{R}$ & $\mathrm{R}$ & $\mathrm{R}$ & $\mathrm{R}$ & $\mathrm{R}$ & $\mathrm{R}$ & $\mathrm{R}$ & $\mathrm{R}$ & $\mathrm{R}$ & $\mathrm{R}$ & $\mathrm{R}$ & $S$ \\
\hline \multicolumn{18}{|l|}{ Yeast } \\
\hline $\begin{array}{c}C . \\
\text { Albicans } \\
\end{array}$ & $\mathrm{R}$ & $S$ & $\mathrm{R}$ & $\mathrm{R}$ & $\mathrm{R}$ & $\mathrm{R}$ & $\mathrm{R}$ & $\mathrm{R}$ & $\mathrm{R}$ & $\mathrm{R}$ & $\mathrm{R}$ & $\mathrm{R}$ & $\mathrm{R}$ & $\mathrm{S}$ & $S$ & $\mathrm{~S}$ & $S$ \\
\hline $\mathrm{R} \%$ & 100 & 33 & 100 & 100 & 100 & 100 & 78 & 100 & 100 & 100 & 100 & 100 & 89 & 78 & 89 & 89 & 22 \\
\hline
\end{tabular}

Ligands: $\mathbf{A}=$ salicyladazire (SA) ; B=4-nitro-benzaldazine (NA) ; C=4-dimethylamino-benzaldazine (DMAA);D= 3, 4, 5trimethoxybenzaldazine (TMA) ; E=4-bromobenzaldazine (BrA).

In the study for the determination of minimum inhibitory concentration (MIC) of metals; $\mathrm{Cd}$ (IV), $\mathrm{Zr}$ (II), Ligands and complexes, on the growth of bacterial isolates shown from inTable (4), that the concentration of $0.00025 \mathrm{~g} /$ disc was the lowest inhibitory concentration and reached the following percentages: 77, 30, 11, 27, 5, 74, 58 and 100\% in each bacterium ; Bacillus subtilus, Staphylococcus aureus, E.coli, Salmonella typhi, Pseudomonas, Proteus vulgaris, Klebsilla pneumonia, Shigella flexneri, respectively, and $16 \%$ in yeast Candida albicans, it was also shown that Cd and Ligand 30B at this concentration, had an effect of 88 and $100 \%$ as the lowest inhibitory concentration for the growth of all bacterial isolates of different species. 
Journal of Education and Science (ISSN 1812-125X), Vol: 30, No: 3, 2021 (63-72)

Special Issue for Proceeding of $3^{\text {rd }}$ National (1 ${ }^{\text {st }}$ international conference of biology) (ICBSUM 2021) 5, 6 July

College of Education for Pure Science, University of Mosul, Mosul, Iraq.

Table (4): Minimum inhibition concentration of $\mathrm{Zr}$ (IV), Cd (II) metals, ligands and complexes on growth of bacteria.

\begin{tabular}{|c|c|c|c|c|c|c|c|c|c|c|c|c|c|c|c|c|c|c|}
\hline \multirow[b]{3}{*}{ Bacteria } & \multicolumn{17}{|c|}{$\mathrm{MIC}$ (g/disc) } & \multirow{3}{*}{$\begin{array}{c}\mathrm{R} \\
(\%)\end{array}$} \\
\hline & \multicolumn{2}{|c|}{ Metals } & \multicolumn{5}{|c|}{ Ligands } & \multicolumn{5}{|c|}{ Zr (IV) Complexes } & \multicolumn{5}{|c|}{ Cd (II) Complexes } & \\
\hline & $\begin{array}{l}\mathrm{Zr} \\
\text { (IV) }\end{array}$ & $\begin{array}{l}\mathrm{Cd} \\
\text { (II) }\end{array}$ & A & B & $\mathrm{C}$ & $\mathrm{D}$ & $\mathrm{E}$ & A & $\mathrm{B}$ & $\mathrm{C}$ & $\mathrm{D}$ & $\mathrm{E}$ & A & $\mathrm{B}$ & $\mathrm{C}$ & $\mathrm{D}$ & $\mathrm{E}$ & \\
\hline \multicolumn{19}{|l|}{ Gram+ve } \\
\hline B.sutilus & 2 & 5 & 2 & 5 & 5 & 5 & 5 & 5 & 5 & 5 & 5 & 5 & 5 & 5 & 5 & 5 & 5 & 77 \\
\hline S.aureus & 2 & 5 & 1 & 1 & 1 & 1 & 5 & 1 & 1 & 1 & 1 & 1 & 2 & 5 & 5 & 5 & 5 & 30 \\
\hline \multicolumn{19}{|l|}{ Gram-ve } \\
\hline E.coli & 2 & 5 & 1 & 1 & 1 & 2 & 5 & 1 & 1 & 1 & 1 & 1 & 1 & 6 & 3 & 3 & 1 & 11 \\
\hline S.typhi & 2 & 5 & 5 & 5 & 5 & 5 & 5 & 1 & 1 & 1 & 1 & 1 & 6 & 3 & 3 & 3 & 3 & 26 \\
\hline P.aeuroginosa & 2 & 3 & 2 & 2 & 2 & 3 & 5 & 1 & 1 & 1 & 1 & 1 & 1 & 1 & 1 & 1 & 1 & 5.0 \\
\hline P. vulgaris & 2 & 5 & 5 & 5 & 5 & 5 & 5 & 1 & 5 & 5 & 5 & 5 & 5 & 5 & 5 & 5 & 5 & 74 \\
\hline K.pneumonia & 2 & 5 & 1 & 1 & 4 & 2 & 5 & 5 & 5 & 5 & 5 & 5 & 5 & 5 & 5 & 5 & 3 & 58 \\
\hline S.flexneri & 5 & 5 & 5 & 5 & 5 & 5 & 5 & 5 & 5 & 5 & 5 & 5 & 5 & 5 & 5 & 5 & 5 & 100 \\
\hline \multicolumn{19}{|l|}{ Yeast } \\
\hline C.albicans & 5 & 5 & 1 & 1 & 1 & 1 & 5 & 2 & 2 & 2 & 2 & 2 & 2 & 2 & 2 & 2 & 2 & 16 \\
\hline $\mathrm{R}(\%)$ & 22 & 88 & 33 & 44 & 44 & 44 & 100 & 22 & 44 & 44 & 44 & 22 & 44 & 55 & 55 & 55 & 33 & \\
\hline
\end{tabular}

Ligands: $\mathbf{A}=$ salicyladazire (SA) ; B=4-nitro-benzaldazine (NA) ; C=4-dimethylamino-benzaldazine (DMAA) ; D= 3, 4, 5trimethoxybenzaldazine (TMA); $\mathbf{E}=4$-bromobenzaldazine $(\mathrm{BrA})$.

MIC: $1=0.01,2=0.002,3=0.001,4=0.0005,5=0.00025,6=0.00005 \mathrm{~g} / \mathrm{disc}$

The results of the statistical analysis showed at a probability level at $\mathrm{P} \leq 0.05$, identical to the results we obtained, which is the superiority of the metal Cd (II) over the metal $\mathrm{Zr}$ (VI) as well as $30 \mathrm{~B}$ Ligand over the other types under study, or when they interact to form a complex compound, in its effect on the growth of bacteria in terms of the inhibition values around the saturated discs with each one and each separately.

\section{References}

[1] G.Manoussakis, C.Bolos, L.Ecateriniadou and C.Sarris, "Synthesis, characterization and antibacterial studies of mixed-ligand complexes of dithiocarbamato - thiocyanato and iron (III), nickel (II), copper (II) and zinc (II)," European Journal of Medicinal Chemistry,vol. 22, no. 5,pp. 421425, 1987, https://doi.org/10.1016/0223-5234(87)90030-4.

[2] M.J. Cleare, “Transition metal complexes in cancer chemotherapy,"Coord.Chem.Rev., vol. 12, no. 4, pp. 349-405, 1974, https://doi.org/10.1016/S0010-8545(00)82029-9.

[3] A.I.Stetsenko, M. A.Presnov and A. L. Conovalova,'The Chemistry of Antitumour Platinum Complexes"Russ.Chem.Rev., vol. 50, no. 4, pp. 353,1981. 
[4] W. J. Stratton and D. H. Busch, "The Complexes of Pyridinaldazine. III. Infrared Spectra and Continued Synthetic Studies,” J.Am.Chem.Soc., vol. 82, no. 18, pp. 4834-4839, 1960, https://doi.org/10.1021/ja01503a021.

[5] J.Lemire, J.J. arrison and R.J.Turner, "Antimicrobial activity of metals: mechanisms, molecular targets,andapplications,"Nat.Rev.Microbiol.,vol.11,no.6,pp.371-384,2013,doi:10.1038/nrmicro3028.

[6] R.J. Turner, "Metal-based antimicrobial strategies."Microbial. Biotechnology, vol. 10, no. 5, pp. 1062-1065, 2017, doi:10.1111/1751-7915.12785.

[7] S.S. Abd Elsalam, R. H. A. M .Taha, M.O.Tawfeik, Abd El-Monem and H.A. Mahmoud, "Antimicrobial Activity of Bio and Chemical Synthesized Cadmium Sulfide Nanoparticles," The Egyptian Journal of Hospital Medicine, vol.70 ,no. 9, pp. 1494-1507 ,2018, doi :10.12816/0044675.

[8] J. F. MacFaddin, "Biochemical tests for identification of medical bacteria," 3rd ed. Lippincott Williams \& Wilkins, Philadelphia, PA.USA.

[9] J.Collee, A.Fraser, B.Marmion, and A.Bimon, "Practical Medical Microbiology, 14th, Churchill Livingstone, New York, USA., p978,1996.

[10] S.P.Saravana Bhavan, R.Rajkumar, S.Radhakrishnan, C.Seenivasan and S.Kanan,"Culture and identification of Candida albicans vaginal ulcer and separation of Enolase on SDS-PAGE," International J. of Biology,vol. 2, no.1, pp. 84-93, 2009,doi: 10.5539/ijb.v2n1p84.

[11]Z.F.Dawood and S.I.Dawood, "Synthesis and characterization of some Zr(IV), AND Cd(II) complexes," Iraqi J. of Chem., vol.,19, no.1, pp.1-10,1994.

[12] D.A.Goldman, R.A.Weinstein, R.P.Wenzel, O.C.Tablan, R.J.Duma, R.P.Gaynes, J.Schlosser and W.J. Martone, "Strategies to prevent and control the emergence and spread of antimicrobialresistant micro-organisms in hospitals: A challenge to hospital leadership," Journal of the American Medical Association., vol. 275, no. 3, pp.234-240,1996.

[13] D. E. Volpato, L. G. D. Rosa, C. A. S. Daudt, B. V.de-Souza, L. H.Melo and L. Deboni, "Use of Antibiotics without Medical Prescription,” Brazilian Journal of Infectious Diseases, vol. 9, no.4, pp. 288-91, 2005, https://doi.org/10.1590/S1413-86702005000400004.

[14] S.Cesur, and A.Demiroz, "Antibiotics and the mechanisms of resistance to antibiotic Medical," Journal of Islamic World Academy of Sciences, vol. 21, no. 4, pp. 138-142, 2013, doi: $\underline{10.12816 / 0002645}$.

[15] N.A. Lerminiaux, and A. D. S. Cameron, "Horizontal transfer of antibiotic resistance genes in clinical environments," Canadian journal of microbiology, vol. 65, no.1, pp. 34-44, 2019, doi: 10.1139/cjm-2018-0275. 
Journal of Education and Science (ISSN 1812-125X), Vol: 30, No: 3, 2021 (63-72)

Special Issue for Proceeding of $3^{\text {rd }}$ National (1 ${ }^{\text {st }}$ international conference of biology) (ICBSUM 2021) 5, 6 July

College of Education for Pure Science, University of Mosul, Mosul, Iraq.

[16] P.Blanco, S.Hernando-Amado, J.A.Reales-Calderon, F.Corona, F.Lira, M.Alcalde-Rico, M. Alcalde-Rico, A.Bernardini, M.B.Sanchez, and J.L.Martinez, "Bacterial Multidrug Efflux Pumps: Much More Than Antibiotic Resistance Determinants: A review,",Microorganisms, vol. 4 ,no.14, pp. 1-19, 2016,doi: 10.3390/microorganisms4010014.

[17] G.Kapoor, S.Saigal, and A.Elongavan, “Action and resistance mechanisms of antibiotics: A guide for clinicians, $J$ Anaesthesiol Clin Pharmacol., vol.33 ,no.3, pp. 300-305,2017,doi: 10.4103/joacp.JOACP_349_15.

[17] U.N. Streip, and R.E. Yasbin, Modern Microbial Genetics.2thed. Wiley-Liss, Inc., New York, pp.672, 2002.

[19] Z.Abd El-Wahab, M.M.Mashaly, A.A.Salman, B.A.El-Shetary, and A.Faheim, "Co (II), Ce (III) and UO 2 (VI) bis-salicylatothiosemicarbazide complexes: Binary and ternary complexes, thermal studies and antimicrobial activity," Spectrochimica Acta Part A, Molecular and Biomolecular Spectroscopy, vol.60, no.12, pp. 2861-2873, 2004,doi: 10.1016/j.saa.2004.01.021.

[20] I.N.Witwit, Z.Yosif, and H.M.Mubark, "Synthesis, Characterization, and Biological Efficacy on new mixed ligand complexes based from azo dye of 8-hydroxy quinoline as a primary ligand and imidazole as a secondary ligand with some of transition metal ions", Journal of Pharmaceutical Sciences and Research, vol. 10, no.12, pp.3074-3082, 2018.

[21] S.D.M. AL-Radwani, "Study the genetic basis of some morphological characters for Proteus bacteria isolated from medical samples," University of Mosul, College of Education, M.Sc.Thesis, Biology/Biotechnology,2012.

[22] C.C.Nguyen, C.N.Hugie, M.L.Kile, and T.Navab-Daneshmand, "Association between heavy metals and antibiotic-resistant human pathogens in environmental reservoirs: A review," Frontiers of Environmental Science and Engineering, vol.13, no.3, pp.1-17, 2019. 